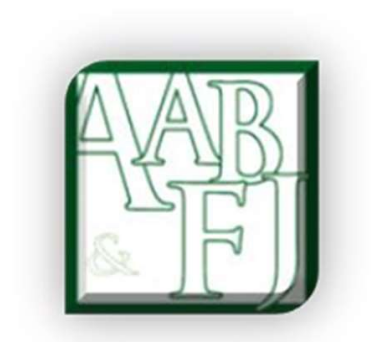

\title{
Editorial: AABFJ Volume 12, Issue 1, 2018
}

\author{
Monir Mir ${ }^{1}$ and Ciorstan Smark $^{2}$
}

Six papers have been published in this issue of Australasian Accounting, Business \& Finance Journal. Two of the papers have dealt with issues relating to small and medium enterprise, two of the papers dealt with stock markets and the rest of the two have dealt with research methods and methodologies.

Cherry, McGrath and Bauman (2018) have investigated and identified the determinants of trust in business relationship between Australia's public accounting firms and their small and medium-sized clients. Research studies involving issues relating to Big-4 accounting firms are abundant. Research involving smaller accounting firms who hold larger audit and advisory market share of the small and medium enterprise are often neglected. Cherry et al.'s (2018) study not only empirically identified the determinants of trusts in the business relationship between smaller accounting firm and small and medium enterprises, but also provided insights on how important such relationship is for advancing their respective businesses. Cherry et al.'s (2018) study is conducted in Australian context. More studies on developing and emerging economy context will fill in the academic and practice gaps in this area of research.

The other paper that have dealt with small and medium enterprise is written by Siddik and Kabiraj (2018). An inclusive society outperforms a non-inclusive society because a noninclusive society faces social unrests which hinders societal advancements. Siddik and Kabiraj has provided empirical evidence that a society could achieve financial stability if small and medium enterprises are included in broader financial mechanisms of the society. Like the study of Cherry et al. (2018), Siddik and Kabiraj (2018) have provided insights on the importance studies involving small and medium enterprises and have called for further studies in this area.

Two of the papers that have dealt with stock market are by Ghasemi, Razak and Muhamad (2018) and by Jorjani and Gerayli (2018). Ghasemi et al. (2018) investigated the causal relationship between dividend payout decisions and debt policies of Malaysian listed companies. Jorjani and Gerayli (2018) investigated auditors' impacts on stock price volatility in the Iranian stock market. Studies on these issues of stock market is abundant but mostly are conducted in the developed economies contexts. Empirical findings gathered in developed economies contexts often cannot be applied in developing countries' contexts as they differ significantly in terms of macro and micro stock market regulatory and governance matters.

Ghasemi et al.'s (2018) and Jorjani and Gerayli's (2018) studies therefore have made significant contributions to the already under-researched stock market research areas of developing and emerging economies.

\footnotetext{
${ }^{1}$ University of Canberra, Australia

${ }^{2}$ University of Wollongong, Australia
} 
Apan, Öztel and İslamoğlu (2018) compared the effectiveness and suitability of Altman ZScore and the VIKOR methods in predicting corporate bankruptcy. Using data of food and drink sector companies listed in Turkish stock exchange (Borsa Istanbul), Apan et al. found that both the Altman Z-Score and VIKOR model will produce similar bankruptcy prediction results and could be used to complement each other. They have insisted that VIKOR method could also be used in predicting bankruptcy under the situation when unavailability of data restricts the use of Altman Z-Score for predicting bankruptcy. Apan et al.'s (2018) findings should enhance confidence of the market analysts in using the VIKOR method.

Salampessy, Triyuwono, Irianto and Hariadi's (2018) paper has proposed a research paradigm supplementing either scientific-positivist paradigm or interpretivist paradigm in accounting research based on five pillars of Indonesia's state philosophy 'Pancasila'. Salampessy et al. (2018) argue that neither scientific-positivistic paradigm nor alternative and interpretivist paradigm will be able to find the spiritual truth from the research. Salampessy et. al. (2018) argued that neither of these paradigms discuss about God as an absolute realty nor do they consider that God sets the legal system of nature and compliance. They have proposed that researchers should understand and adopt spiritual reality to reach for the level of God's attributes as a supplement to either positivist or interpretivist paradigms of research. Otherwise, researchers will be working solely for benefitting themselves out of their research and will be ignoring the interests of the wider society. It is expected that Salampessy et al.'s (2018) proposition will encourage research methodology paradigm debates among academics and at the same time it would be interesting to see whether their proposition of adopting spirituality within the existing research methodologies will bring benefits to society.

\section{References}

Apan, Mehmet; Öztel, Ahmet; and İslamoğlu, Mehmet, Comparative Empirical Analysis of Financial Failures of Enterprises with Altman Z-Score and VIKOR Methods: BIST Food Sector Application, Australasian Accounting, Business and Finance Journal, 12(1), 2018, 77-101. doi:10.14453/aabfj.v12i1.6

DOI http://dx.doi.org/10.14453/aabfj.v12i1.6

Cherry, Michael; McGrath, Dianne; and Baumann, Chris, Client Intimacy \& Performance Advice: Determinants of Trust in the Public Accountant - SME Client Relationship, Australasian Accounting, Business and Finance Journal, 12(1), 2018, 3-32. doi:10.14453/aabfj.v12i1.2 DOI http://dx.doi.org/10.14453/aabfj.v12i1.2

De Zoysa, Anura, Vale Professor Hema Wijewardena: Quest for knowledge, Australasian Accounting, Business and Finance Journal, 12(1), 2018, 116-125. doi:10.14453/aabfj.v12i1.8 DOI http://dx.doi.org/10.14453/aabfj.v12i1.8

Ghasemi, Maziar; AB Razak, Nazrul; and Muhamad, Junaina, Dividends, Leverage and Endogeneity: A Simultaneous Equations Study on Malaysia, Australasian Accounting, Business and Finance Journal, 12(1), 2018, 47-64. doi:10.14453/aabfj.v12i1.4

DOI http://dx.doi.org/10.14453/aabfj.v12i1.4

Jorjani, Mehran and Safari Gerayeli, Mehdi, Auditor Tenure and Stock Price Volatility: The Moderating Role of Auditor Industry Specialization, Australasian Accounting, Business and Finance Journal, 12(1), 2018, 65-76. doi:10.14453/aabfj.v12i1.5

DOI http://dx.doi.org/10.14453/aabfj.v12i1.5

Salampessy, Zulkarim; Triyuwono, Iwan; Irianto, Gugus; and Hariadi, Bambang, Pancasila Paradigm: Methodology of Wawasan Nusantara for Accounting of Pancasila, Australasian Accounting, Business and Finance Journal, 12(1), 2018, 102-115. doi:10.14453/aabfj.v12i1.7

DOI http://dx.doi.org/10.14453/aabfj.v12i1.7

Siddik, Md. Nur Alam and Kabiraj, Sajal, Does Financial Inclusion Induce Financial Stability? Evidence from Cross-country Analysis, Australasian Accounting, Business and Finance Journal, 12(1), 2018, 34-46. doi:10.14453/aabfj.v12i1.3

DOI http://dx.doi.org/10.14453/aabfj.v12i1.3 